\title{
molecules
}

ISSN 1420-3049

(C) 2007 by MDPI

www.mdpi.org/molecules

\author{
Full Paper
}

\section{Synthesis and Activity of a New Series of (Z)-3-Phenyl-2-benzoylpropenoic Acid Derivatives as Aldose Reductase Inhibitors}

\author{
Shao-Jie Wang ${ }^{1, *}$, Ju-Fang Yan ${ }^{2}$, Dong Hao ${ }^{1}$, Xin-Wen Niu ${ }^{1}$ and Mao-Sheng Cheng ${ }^{1}$ \\ ${ }^{1}$ Key Laboratory of New Drugs Design and Discovery of Liaoning Province, Shenyang \\ Pharmaceutical University, Shenyang 110016, P.R. China \\ 2 Drug Screening Center, Di Ao Pharmaceutical Group, Chengdu 123388, P.R. China \\ * Author to whom correspondence should be addressed; E-mail: sjwang_99@yahoo.com.cn; \\ Tel: (+86)24-23986421; Fax: (+86)24-23986421
}

Received: 21 March 2007; in revised form: 23 April 2007 / Accepted: 23 April 2007 / Published: 30 April 2007

\begin{abstract}
During the course of studies directed towards the discovery of novel aldose reductase inhibitors for the treatment of diabetic complications, we synthesized a series of new (Z)-3-phenyl-2-benzoylpropenoic acid derivatives and tested their in vitro inhibitory activities on rat lens aldose reductase. Of these compounds, (Z)-3-(3,4-dihydroxyphenyl)2-(4-methylbenzoyl)propenoic acid (3k) was identified as the most potent inhibitor, with an $\mathrm{IC}_{50}$ of $0.49 \mu \mathrm{M}$. The theoretical binding mode of $3 \mathbf{k}$ was obtained by simulation of its docking into the active site of the human aldose reductase crystal structure.
\end{abstract}

Keywords: (Z)-3-Phenyl-2-benzoylpropenoic acid, aldose reductase inhibitor, structureactivity relationships

\section{Introduction}

Aldose reductase (ALR2, EC1.1.1.21) is an enzyme that catalyzes the conversion of glucose to sorbitol, which in turn is converted into fructose by sorbitol dehydrogenase. Glucose metabolized through this pathway has been linked to complications of long-term diabetes such as cataracts, 
retinopathy, nephropathy and neuropathy. As a result, aldose reductase inhibitors (ARIs) have been proposed as therapeutic agents for preventing or treating diabetic complications [1].

A variety of structurally different compounds have been reported to act as ARIs, and they can be divided into two general groups: those containing rigid spirohydantoins or a related ring system, such as Sorbinil, and those like Epalrestat and Zenarestat, which contain a carboxylic acid moiety (Figure 1). In these last molecules a planar aromatic structure with a carboxylic or another acidic proton appears to be essential for the inhibitory effect $[2,3]$.

Figure 1. Potential aldose reductase inhibitors.<smiles>O=C1NC(=O)[C@]2(CCOc3ccc(F)cc32)N1</smiles>

Sorbinil<smiles>O=C(O)Cn1c(=O)n(Cc2ccc(Br)cc2F)c(=O)c2ccc(Cl)cc21</smiles>

Zenarestat<smiles>CC(/C=C1\SC(=S)N(CC(=O)O)C1=O)=C\c1ccccc1</smiles>

Epalrestat<smiles>O=C(O)/C(=C\c1ccc(O)c(O)c1)C(=O)c1ccccc1</smiles>

1

Chalcones, considered as the precursor of flavonoids and isoflavonoids, are abundant in edible plants [4], and have also been shown to display a diverse array of pharmacological activities, such as anti-protozoal [5], anti-inflammatory [6], anticancer [7] and antihyperglycemic properties [8]. Consequently, the chalcone backbone could be a versatile scaffold for drug design. A survey of the literature revealed that some natural $[9,10]$ and synthetic chalcones [11] showed significant ALR2 inhibitory activities, and this prompted us to investigate potential ARIs derived from chalcone-based compounds. Thus, we focused on the compounds having a carboxylic acid moiety that was incorporated into the chalcone backbone and synthesized these compounds. Initially we focused our attention on (Z)-3-phenyl-2-benzoylpropenoic acid derivatives, in which the carboxylic acid group was introduced into the $\alpha$-position of the chalcone backbone, since the synthesis of such (Z)-3-phenyl-2benzoylpropenoic acid derivatives for ALR2 inhibitory activity appears to be an unexplored field. Indeed, our preliminary study demonstrated that some (Z)-3-phenyl-2-benzoylpropenoic acid derivatives, such as compound 1, displayed potent ALR2 inhibitory activities with a potency comparable to that of Epalrestat [12]. In this paper, we report the synthesis and ALR2 inhibitory activity of a new series of (Z)-3-phenyl-2-benzoylpropenoic acid derivatives. Moreover, molecular modeling of the structure of the complex between human ALR2 and the most active derivative of the new series (3k) was performed. 


\section{Results and Discussion}

As illustrated in Scheme 1, a series of ethyl benzoylacetates were condensed with a range of benzaldehydes in the presence of acetic acid in toluene and using 6-aminohexanoic acid as a catalyst to give ethyl (Z)-3-phenyl-2-benzoylpropenates 2a-o [13] via Knoevenagel reactions. The products were hydrolyzed with $6 \mathrm{~N} \mathrm{NaOH}$ in ethanol and subsequently acidified with $6 \mathrm{~N} \mathrm{HCl}$ to afford the (Z)-3phenyl-2-benzoylpropenoic acid derivatives 3a-o in modest overall yields (13-43\%). We attribute these low yields to the inherent instability of the $\beta$-ketoacid targets, as well as the product losses arising from the need to recrystallize the products repeatedly to obtain them in pure form.

Scheme 1. Synthesis of (Z)-3-phenyl-2-benzoylpropenoic acid derivatives.

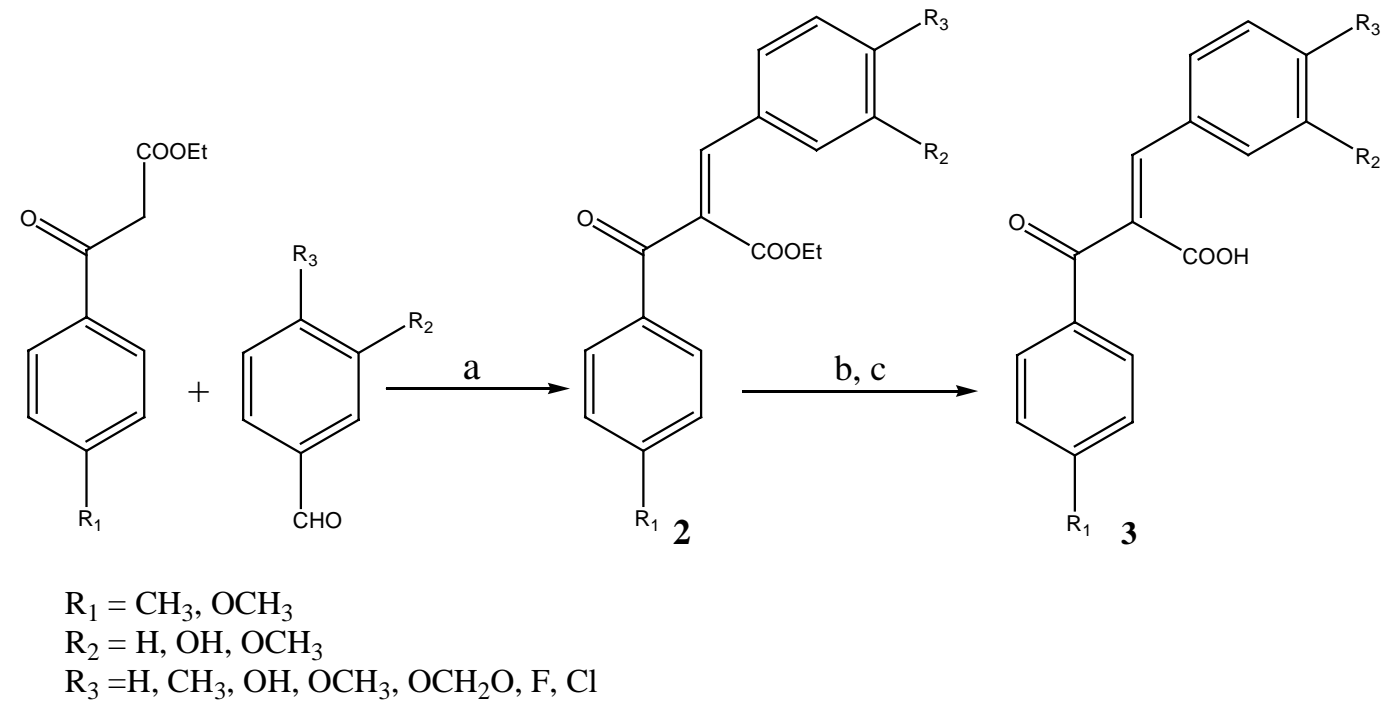

Reagents and conditions: (a) $\mathrm{CH}_{3} \mathrm{COOH}, \mathrm{H}_{2} \mathrm{~N}\left(\mathrm{CH}_{2}\right)_{5} \mathrm{COOH}$, PhMe, reflux; (b) $6 \mathrm{~N} \mathrm{NaOH}$, EtOH, r.t.; (c) $6 \mathrm{~N} \mathrm{HCl}$.

\section{Aldose reductase inhibitory activity}

All compounds synthesized were tested in vitro for their ability to inhibit ALR2 with an enzyme preparation from rat lenses, using Epalrestat as a reference drug (Table 1). The enzyme activity was assayed by spectrophotometrically monitoring the consumption of NADPH cofactor at $340 \mathrm{~nm}$ using $D, L$-glyceraldehyde as substrate [14].

The ALR2 inhibition data reported in Table 1 show that in general the activity of this class of compound is minimal, but it appeared to be influenced both by the nature and by the position of the substituents on the benzoyl (ring A) and phenyl (ring B) moieties. Compound 3k, with 3',4'-dihydroxyl groups on ring $\mathrm{B}$ and a 4-methyl group on ring $\mathrm{A}$ was the most potent inhibitor, with an $\mathrm{IC}_{50}$ of 0.49 $\mu \mathrm{M}$. When a 4-methoxy group replaced the 4-methyl group, the resulting compound exhibited much lower activity (3I, $\mathrm{IC}_{50}=30.84 \mu \mathrm{M}$ ). In the case of compounds $\mathbf{3 e}$ and $\mathbf{3 m}$, where the 3',4'-dihydroxyl groups on ring $\mathrm{B}$ were masked with a methylene group, no significant inhibitory effect was observed. Replacing the 3'-hydroxyl group of compound 3k with a methoxy group lowered the activity 32-fold 
$\left(3 \mathbf{j}, \mathrm{IC}_{50}=15.69 \mu \mathrm{M}\right)$. Compound $3 \mathbf{i}\left(\mathrm{IC}_{50}=7.59 \mu \mathrm{M}\right)$ was two times more effective than compound $\mathbf{3} \mathbf{j}$, whereas compound $\mathbf{3 b}$, with the positions of the $\mathrm{H}$ and methoxy groups reversed, was inactive.

Table 1. In vitro rat lens aldose reductase inhibition data of (Z)-3-phenyl-2-benzoylpropenoic acid derivatives.

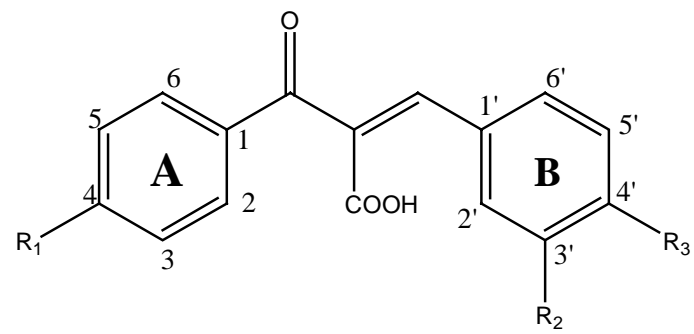

\begin{tabular}{|c|c|c|c|c|}
\hline Compds & $\mathbf{R}_{1}$ & $\mathbf{R}_{2}$ & $\mathbf{R}_{3}$ & $I C_{50}(\mu M)^{a}$ \\
\hline $3 a$ & $\mathrm{CH}_{3}$ & $\mathrm{H}$ & $\mathrm{H}$ & n.a. ${ }^{b}$ \\
\hline $3 \mathbf{b}$ & $\mathrm{CH}_{3}$ & $\mathrm{H}$ & $\mathrm{OCH}_{3}$ & n.a. \\
\hline $3 c$ & $\mathrm{CH}_{3}$ & $\mathrm{H}$ & $\mathrm{F}$ & n.a. \\
\hline 3d & $\mathrm{CH}_{3}$ & $\mathrm{H}$ & $\mathrm{Cl}$ & n.a. \\
\hline $3 \mathbf{e}$ & $\mathrm{CH}_{3}$ & \multicolumn{2}{|c|}{$\mathrm{OCH}_{2} \mathrm{O}$} & n.a. \\
\hline $3 f$ & $\mathrm{CH}_{3}$ & $\mathrm{H}$ & $\mathrm{OH}$ & n.a. \\
\hline $3 g$ & $\mathrm{CH}_{3}$ & $\mathrm{OH}$ & $\mathrm{H}$ & n.a. \\
\hline $3 h$ & $\mathrm{CH}_{3}$ & $\mathrm{H}$ & $\mathrm{CH}_{3}$ & n.a. \\
\hline $3 \mathbf{i}$ & $\mathrm{CH}_{3}$ & $\mathrm{OCH}_{3}$ & $\mathrm{H}$ & 7.95 \\
\hline $3 \mathbf{j}$ & $\mathrm{CH}_{3}$ & $\mathrm{OCH}_{3}$ & $\mathrm{OH}$ & 15.69 \\
\hline $3 \mathbf{k}$ & $\mathrm{CH}_{3}$ & $\mathrm{OH}$ & $\mathrm{OH}$ & 0.49 \\
\hline 31 & $\mathrm{OCH}_{3}$ & $\mathrm{OH}$ & $\mathrm{OH}$ & 30.84 \\
\hline $3 \mathrm{~m}$ & $\mathrm{OCH}_{3}$ & \multicolumn{2}{|c|}{$\mathrm{OCH}_{2} \mathrm{O}$} & n.a. \\
\hline $3 n$ & $\mathrm{OCH}_{3}$ & $\mathrm{H}$ & $\mathrm{Cl}$ & n.a. \\
\hline 30 & $\mathrm{OCH}_{3}$ & $\mathrm{OH}$ & $\mathrm{H}$ & n.a. \\
\hline Epalrestat & & & & 0.075 \\
\hline
\end{tabular}

${ }^{\mathrm{a}} \mathrm{IC}_{50}$ values represent the concentration required to produce 50 $\%$ enzyme inhibition; ${ }^{\mathrm{b}}$ n.a. = not active (less than $50 \%$ inhibition at $10 \mu \mathrm{g} / \mathrm{mL}$, the highest possible concentration before precipitation of the compounds in the assay solution).

\section{Molecular modeling}

To better understand the fairly good ALR2 inhibitory potency of compound $3 \mathbf{k}$ at the molecular level, experimental docking into the binding pocket of the human ALR2/NADP ${ }^{+} /$IDD594 complex (PDB entry code 1US0) was performed. The docking experiment was carried out using the FlexX program [15], and the carboxylic group of compound 3k was calculated in dissociated form.

Although the inhibition assays on our compounds were conducted on rat ALR2, the use of the crystal structure of the human ALR2 for docking study seems reasonable according to the following facts: (i) the crystal structure of rat ALR2 is unknown; (ii) the human and rat sequences of this enzyme 
are characterized by $85 \%$ identity [16]; (iii) all active-site residues are largely conserved across the ALR2 isoforms sequenced so far [17].

The energy-minimized structure of IDD594 was preliminarily docked into ALR2 to examine how closely the FlexX algorithm can reproduce the binding modes observed in the crystallographic structure. A superposition of docked IDD594 onto the crystallographic geometry yielded a root mean square deviation (RMSD) of $0.97 \AA$. The hydrogen bonds predicted by FlexX were virtually identical to those found in the crystal structure.

Figure 2. Amino acid residues interacting with compound $3 \mathbf{k}$ (orange) in the structure of the enzyme-inhibitor complex. Hydrogen bonds are represented by dashed yellow lines.

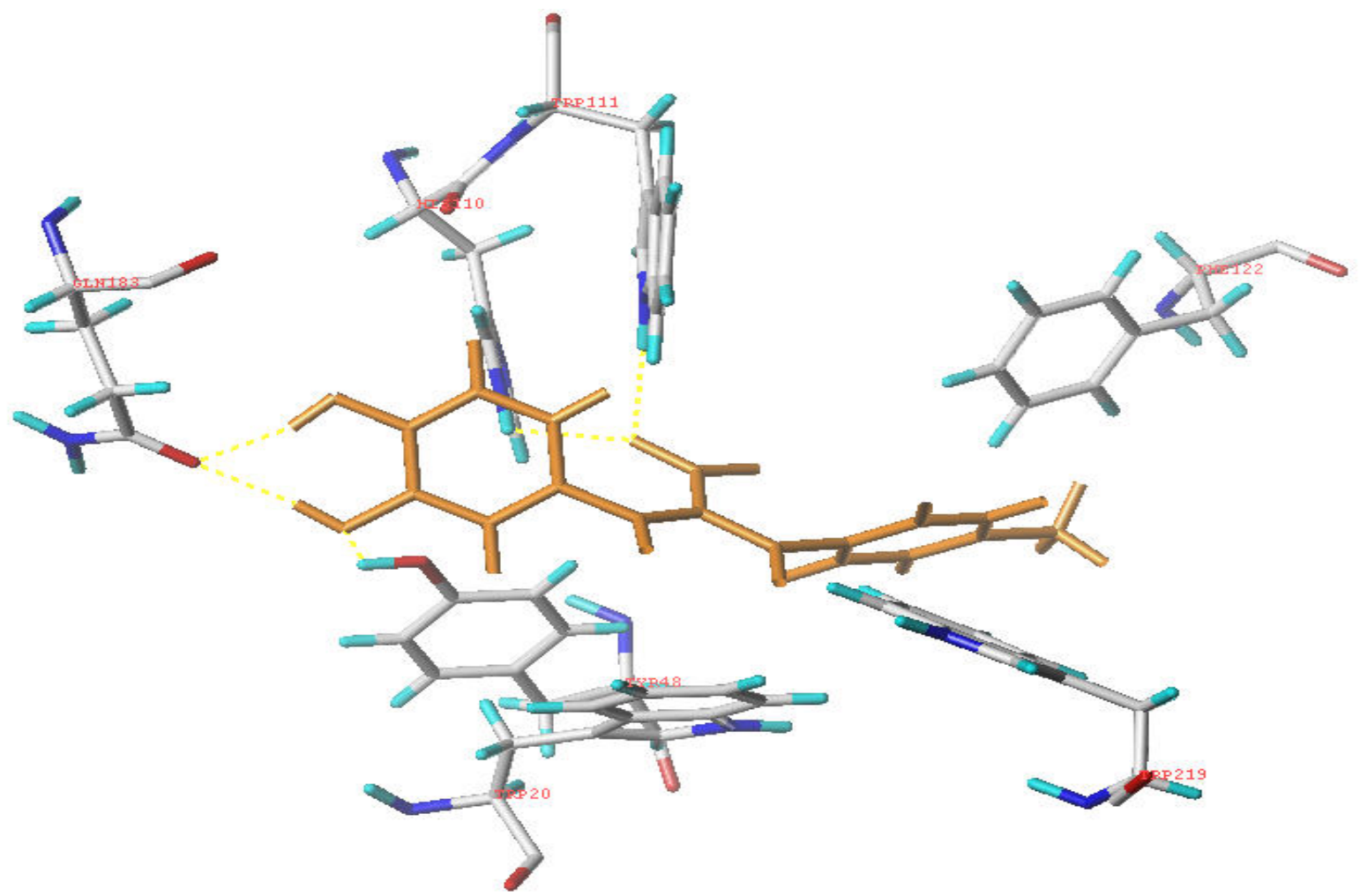

It is known from the crystal structures of complexes of ALR2 with carboxylic acid inhibitors that these bind ALR2 with the carboxylate moiety interacting with Tyr48, His110, and Trp111, which are the three key residues involved in binding [17]. Accordingly, compound $\mathbf{3 k}$ was expected to bind ALR2 with its carboxylate moiety in a similar position. As shown in Figure 2, compound 3k indeed forms hydrogen bonds with His110 and Trp111 through the carboxylate moiety, as expected, but the fact that the 3',4'-dihydroxyl groups on ring B form hydrogen bonds with Gln183 and the 3'-hydroxyl group forms an additional hydrogen bond with Tyr48 was unexpected, and we conclude that all these hydrogen bonds might constitute a tight hydrogen bond network that helps to anchor the carboxylic acid group into the anion binding site. The A ring is inserted into the hydrophobic pocket lined by the residues Trp20, Phe122 and Trp219. The binding mode of compound 3k with ALR2 could help to rationalize its potency, and the results suggest that the $\mathrm{B}$ ring hydroxyl groups of compound $3 \mathbf{k}$ may be helpful for anchoring the compound into the active site, but it is also clear that these factors alone are insufficient to explain the observed activity, since compound 31, which has much lower activity, possesses a similar 3,4 di-OH arrangement on the B ring and differs only in the replacement of the 4$\mathrm{CH}_{3}$ group found in $3 \mathbf{k}$ by a $4-\mathrm{OCH}_{3}$ group, likewise located in the hydrophobic pocket, and 
compounds $\mathbf{3 f}$ and $\mathbf{3 g}$ were inactive, while having at least one free $\mathrm{OH}$ group at either of the B ring $\mathbf{3}^{\prime}$ or $4^{\prime}$ positions. Further SAR investigation through synthesizing more compounds with similar structures might provide more valuable information to clarify these discrepancies. Although the main purpose of the molecular modeling was to better understand the fairly good ALR2 inhibitory activity of compound 3k, rather than intend to compare it with IDD594 specifically, we did find that the binding mode of the carboxylate moiety of compound $3 \mathbf{k}$ with the anion binding site of ALR2 is somewhat different from that of IDD594, in which the carboxylate moiety forms hydrogen bonds with Tyr48, His110, and Trp111 [18], whereas in the case of compound 3k, the carboxylate moiety forms hydrogen bonds with His110 and Trp111 only, and the 3'-hydroxyl group forms a hydrogen bond with Tyr48 instead.

\section{Conclusions}

In summary, the synthesis and ALR2 inhibitory activity of fifteen (Z)-3-phenyl-2-benzoylpropenoic acid derivatives 3a-o are described. The results show that the position and nature of the substituents on rings $\mathrm{A}$ and $\mathrm{B}$ may influence the inhibitory activity. Compound $\mathbf{3 k}$, which displayed the highest potency, with $\mathrm{IC}_{50}$ value in the submicromolar range, will be used as a lead compound for further SAR studies. The docking simulation of compound 3k into the human ALR2 binding site offers a possible explanation for its good activity, and may guide the design of new analogues.

\section{Experimental}

\section{General}

Melting points were taken on an Electrothermal capillary melting point apparatus and are uncorrected. ${ }^{1} \mathrm{H}-\mathrm{NMR}$ spectra were recorded in DMSO- $\mathrm{d}_{6}$ solution on a Bruker ARX-300 spectrometer at $300 \mathrm{MHz}$ with chemical shifts reported in ppm downfield relative to TMS as internal standard. IR spectra were recorded on a Bruker IFS-55 spectrometer, using KBr disks. ESI-MS were obtained on an Agilent 1100 instrument. Elemental analyses were carried out with a Flash-EA 1112 elemental analyzer. All reactions were carried out using commercial grade reagents and solvents.

\section{General procedure for the preparation of (Z)-3-phenyl-2-benzoylpropenoic acids 3a-o}

A mixture of ethyl benzoylacetate $(10 \mathrm{mmol})$, aromatic aldehyde (11 mmol), 6-aminohexanoic acid $(0.1 \mathrm{~g})$, acetic acid $(5 \mathrm{~mL})$ and toluene $(30 \mathrm{~mL})$ was heated under reflux using a Dean Stark apparatus for azeotropic distillation of water, and the reaction was monitored by TLC. After 8-12 hours, toluene was removed by distillation under vacuum, the residue was dissolved in ethyl acetate $(100 \mathrm{~mL})$ and then washed successively with water $(50 \mathrm{~mL}), 5 \% \mathrm{Na}_{2} \mathrm{CO}_{3}(50 \mathrm{~mL} \times 2)$, and brine $(50 \mathrm{~mL} \times 2)$. The organic layer was dried overnight over anhydrous $\mathrm{Na}_{2} \mathrm{SO}_{4}$, filtered and the filtrate was concentrated under vacuum. To the residue ethanol $(20 \mathrm{~mL})$ and $20 \% \mathrm{NaOH}(30 \mathrm{~mL})$ were added and the mixture was stirred at room temperature for 24 hours. After evaporating most of the ethanol, brine $(60 \mathrm{~mL})$ was added into the residue, which was then extracted with ethyl acetate $(40 \mathrm{~mL} \times 3)$. Concentrated $\mathrm{HCl}$ 
was added to adjust the $\mathrm{pH}$ of the water layer to 1 and the mixture was extracted with ethyl acetate (50 $\mathrm{mL} \times 2$ ), the ethyl acetate extracts were combined, dried overnight over anhydrous $\mathrm{Na}_{2} \mathrm{SO}_{4}$, filtered and the filtrate was concentrated to dryness under vacuum. The resulting solids were purified by recrystallization from the indicated solvents to give compounds 3a-o.

(Z)-3-phenyl-2-(4-methylbenzoyl)propenoic acid (3a): Yield: 38 \%; mp: 156-158 ${ }^{\circ} \mathrm{C}\left(\mathrm{EtOH}-\mathrm{H}_{2} \mathrm{O}\right)$; IR $\left(v_{\text {max. }}, \mathrm{cm}^{-1}\right)$ : 3438, 1688, 1673, 1605, 1285; ${ }^{1} \mathrm{H}-\mathrm{NMR} \delta$ : 2.35 (s, 3H, $\mathrm{CH}_{3}$ ), 7.31-7.38 (m, 7H, 3, 5, 2', 3', 4', 5', 6'-H), 7.77-7.80 (d, 2H, J = 8.16 Hz, 2,6-H ), 7.85 (s, 1H, olefin-H), 13.16 (s, 1H, COOH); ESI-MS: $266.9[\mathrm{M}+\mathrm{H}]^{+}$; Anal. Calcd. for $\mathrm{C}_{17} \mathrm{H}_{14} \mathrm{O}_{3}$ : C 76.68, H 5.30. Found: C 76.64, H 5.32.

(Z)-3-(4-methoxyphenyl)-2-(4-methylbenzoyl)propenoic acid (3b): Yield: $29 \%$; mp: 164-166 ${ }^{\circ} \mathrm{C}$ (EtOH-H ${ }_{2} \mathrm{O}$ ); IR ( $v_{\text {max. }}, \mathrm{cm}^{-1}$ ): 3440, 1699, 1659, 1603, 1265; ${ }^{1} \mathrm{H}-\mathrm{NMR} \delta$ : 2.36 (s, 3H, $\mathrm{CH}_{3}$ ), 3.72 (s, $3 \mathrm{H}, \mathrm{OCH}_{3}$ ), 6.86-6.89 (d, 2H,J = 8.73 Hz, 3',5'-H), 7.30-7.32 (d, 2H, J = 8.56 Hz, 2',6'-H ), 7.32-7.35 (d, 2H, J = 7.66 Hz, 3,5-H), 7.77-7.80 (d, 2H, J = 7.96 Hz, 2,6-H), 7.78 (s, 1H, olefin-H), 13.01 (s, 1H, $\mathrm{COOH}$ ); ESI-MS: 296.9 [M+H] $]^{+}$; Anal. Calcd. for $\mathrm{C}_{18} \mathrm{H}_{16} \mathrm{O}_{4}$ : C 72.96, H 5.44. Found: C 72.89, H 5.38.

(Z)-3-(4-fluorophenyl)-2-(4-methylbenzoyl)propenoic acid (3c): Yield: 24 \%; mp: 163-165 ${ }^{\circ} \mathrm{C}$ (EtOH$\left.\mathrm{H}_{2} \mathrm{O}\right)$; IR $\left(v_{\text {max. }}, \mathrm{cm}^{-1}\right)$ : 3380, 1692, 1663, 1600, 1275; ${ }^{1} \mathrm{H}-\mathrm{NMR} \delta: 2.36\left(\mathrm{~s}, 3 \mathrm{H}, \mathrm{CH}_{3}\right), 7.15-7.20(\mathrm{~m}, 2 \mathrm{H}$, 2',6'-H), 7.32-7.35 (d, 2H, J = 8.10 Hz, 3,5-H ), 7.40-7.4 5(m, 2H, 3',5'-H ), 7.77-7.80 (d, 2H, J = 8.32 Hz, 2,6-H), 7.86 (s, 1H, olefin-H), 13.25 (broad s, 1H, COOH); ESI-MS: 284.9 [M+H] ${ }^{+}$; Anal. Calcd. for $\mathrm{C}_{17} \mathrm{H}_{13} \mathrm{FO}_{3}$ : C 71.82, H 4.61. Found: C 71.76, H 4.69.

(Z)-3-(4-chlorophenyl)-2-(4-methylbenzoyl)propenoic acid (3d): Yield: 20 \%; mp: 166-168 ${ }^{\circ} \mathrm{C}$ (EtOH$\mathrm{H}_{2} \mathrm{O}$ ); IR ( $v_{\text {max. }}, \mathrm{cm}^{-1}$ ): 3449, 1700, 1662, 1604, 1277; ${ }^{1} \mathrm{H}-\mathrm{NMR} \delta: 2.30$ (s,3H, $\mathrm{CH}_{3}$ ), 7.32-7.35 (d, 2H, J $\left.=8.13 \mathrm{~Hz}, 2^{\prime}, 6^{\prime}-\mathrm{H}\right), 7.38-7.42\left(\mathrm{~m}, 4 \mathrm{H}, 3,5,3^{\prime}, 5^{\prime}\right), 7.76-7.79$ (d, 2H, J = 8.13 Hz, 2,6-H ), 7.85 (s, 1H, olefin-H), 13.28 (broad s, $1 \mathrm{H}, \mathrm{COOH}$ ); ESI-MS: $300.9[\mathrm{M}+\mathrm{H}]^{+}$; Anal. Calcd. for $\mathrm{C}_{17} \mathrm{H}_{13} \mathrm{ClO}_{3}$ : C 67.89, H 4.36. Found: C 67.93, H 4.37.

(Z)-3-(1,3-benzodioxol-5-yl)-2-(4-methylbenzoyl)propenoic acid (3e): Yield: 43 \%; mp: 184-186 ${ }^{\circ} \mathrm{C}$ (EtOH-H $\left.{ }_{2} \mathrm{O}\right)$; IR ( $\left.v_{\text {max. }}, \mathrm{cm}^{-1}\right)$ : 3430, 1700, 1658, 1602, 1253; ${ }^{1} \mathrm{H}-\mathrm{NMR} \delta: 2.37$ (s, 3H, $\left.\mathrm{CH}_{3}\right), 6.00(\mathrm{~s}$, $2 \mathrm{H}, \mathrm{OCH}_{2} \mathrm{O}$ ), 6.79-9.80 (d, $\left.1 \mathrm{H}, \mathrm{J}=1.59 \mathrm{~Hz}, 2^{\prime}-\mathrm{H}\right), 6.88-6.90$ (d, $1 \mathrm{H}, \mathrm{J}=8.11 \mathrm{~Hz}, 5^{\prime}-\mathrm{H}$ ), 6.97-6.99 (dd, $1 \mathrm{H}, \mathrm{J}=8.24 \mathrm{~Hz}, \quad \mathrm{~J}=1.64 \mathrm{~Hz}, 6^{\prime}-\mathrm{H}$ ), 7.33-7.36 (d, 2H, J = 8.03 Hz, 3,5-H ), 7.77-7.80 (d, 2H, J = 8.17 Hz, 2,6-H ), 7.75 (s, 1H, olefin-H), 13.08 (s, 1H, COOH); ESI-MS: 311.0 [M+H] ; Anal. Calcd. for $\mathrm{C}_{18} \mathrm{H}_{14} \mathrm{O}_{5}$ : C 69.67, H 4.55. Found: C 69.70, H 4.45.

(Z)-3-(4-hydroxyphenyl)-2-(4-methylbenzoyl)propenoic acid (3f): Yield: $15 \%$; mp: 195-197 ${ }^{\circ} \mathrm{C}$ (petroleum ether-EtOAc); IR ( $v_{\text {max. }} \mathrm{cm}^{-1}$ ): 3366, 1678, 1649, 1602, 1281; ${ }^{1} \mathrm{H}-\mathrm{NMR} \delta: 2.36$ (s, 3H, $\mathrm{CH}_{3}$ ), 6.55-6.68 (d, 2H, J = 8.64 Hz, 3',5'-H ), 7.19-7.22 (d,2H, J = 8.67 Hz, 2',6'-H ), 7.31-7.34 (d, $2 \mathrm{H}, \mathrm{J}=8.01 \mathrm{~Hz}, 3,5-\mathrm{H}$ ), 7.73 (s, 1H, olefin-H), 7.76-7.79 (d, 2H, J = 8.12 Hz, 2,6-H ), 10.08 (s, 1H, $\mathrm{OH}$ ), 12.92 (s, 1H, COOH); ESI-MS: $283.0[\mathrm{M}+\mathrm{H}]^{+}$; Anal. Calcd. for $\mathrm{C}_{17} \mathrm{H}_{14} \mathrm{O}_{4}$ : C 72.33, H 5.00. Found: C 72.38, H 5.17. 
(Z)-3-(3-hydroxyphenyl)-2-(4-methylbenzoyl)propenoic acid (3g): Yield: 20 \%; mp: 150-152 ${ }^{\circ} \mathrm{C}$ (petroleum ether-EtOAc); IR ( $v_{\text {max. }} \mathrm{cm}^{-1}$ ): 3350, 1690, 1661, 1603, 1251; ${ }^{1} \mathrm{H}-\mathrm{NMR} \delta: 2.36$ (s, 3H, $\mathrm{CH}_{3}$ ), 6.72-6.81 (m, 3H, 2', 4', 6'-H), 7.07-7.12 (m,1H, 5'-H), 7.31-7.34 (d, 2H, J = 7.91 Hz, 3,5-H), 7.74 (s, 1H, olefin-H), 7.76-7.79 (d, 2H, J = 7.89 Hz, 2,6-H), 9.61 (s,1H, -OH), 13.18 (broad s, 1H, $\mathrm{COOH}$ ); ESI-MS: $283.0[\mathrm{M}+\mathrm{H}]^{+}$; Anal. Calcd. for $\mathrm{C}_{17} \mathrm{H}_{14} \mathrm{O}_{4}$ : C 72.33, H 5.00. Found: C 72.34, H 5.09.

(Z)-3-(4-methylphenyl)-2-(4-methylbenzoyl)propenoic acid (3h): Yield: 23 \%; mp: 167-169 ${ }^{\circ} \mathrm{C}$ (EtOH$\mathrm{H}_{2} \mathrm{O}$ ); IR ( $\left.v_{\text {max., }} \mathrm{cm}^{-1}\right)$ : 3360, 1685, 1664, 1603, 1276; ${ }^{1} \mathrm{H}-\mathrm{NMR} \delta: 2.23$ (s, 3H, CH3), 2.35 (s, 3H, $\mathrm{CH}_{3}$ ), 7.10-7.13 (d, 2H, J = 8.11 Hz, 3',5'-H ), 7.24-7.27 (d, 2H, J = 8.13 Hz, 2',6'-H ), 7.31-7.34 (d, 2H, J = 8.10 Hz, 3,5-H ), 7.77-7.79 (d, 2H, J = 8.13, 2,6-H ), 7.81 (s, 1H, olefin-H), 13.17(s, 1H, $\mathrm{COOH}$ ); ESI-MS: $281.0[\mathrm{M}+\mathrm{H}]^{+}$; Anal. Calcd. for $\mathrm{C}_{18} \mathrm{H}_{16} \mathrm{O}_{3}$ : C 77.12, H 5.75. Found: C 77.03, H 5.69.

(Z)-3-(3-methoxyphenyl)-2-(4-methylbenzoyl)propenoic acid (3i): Yield: 20 \%; mp: 125-127 ${ }^{\circ} \mathrm{C}$ (EtOH-H ${ }_{2} \mathrm{O}$ ); IR ( $v_{\text {max. }} \mathrm{cm}^{-1}$ ): 3430, 1702, 1662, 1603, 1250; ${ }^{1} \mathrm{H}-\mathrm{NMR} \delta: 2.36$ (s, 3H, $\mathrm{CH}_{3}$ ), 3.61 (s, $3 \mathrm{H}, \mathrm{OCH}_{3}$ ), 6.90-6.94 (m, 3H, 2', 3', 5'-H), 7.19-7.22 (m, 1H, 4'-H), 7.32-7.35 (d, 2H, J = 8.08 Hz, 3,5H), 7.78-7.81 (d, 2H, J = 8.11 Hz, 2,6-H), 7.83 (s, 1H, olefin-H), 13.27 (s, 1H, COOH); ESI-MS: 297.0 $[\mathrm{M}+\mathrm{H}]^{+}$; Anal. Calcd. for $\mathrm{C}_{18} \mathrm{H}_{16} \mathrm{O}_{4}$ : C 72.96, H 5.44. Found: C 72.88, H 5.60.

(Z)-3-(4-hydroxy-3-methoxyphenyl)-2-(4-methylbenzoyl)propenoic acid (3j): Yield: 24 \%; mp: 171$173{ }^{\circ} \mathrm{C}$ (petroleum ether-EtOAc); IR $\left(v_{\text {max. }}, \mathrm{cm}^{-1}\right)$ : 3484, 1665, 1656, 1600, 1267; ${ }^{1} \mathrm{H}-\mathrm{NMR} \delta:{ }^{1} \mathrm{H}-\mathrm{NMR}$ $\delta: 2.36$ (s, 3H, $\left.\mathrm{CH}_{3}\right), 3.51$ (s, 3H, $\left.\mathrm{OCH}_{3}\right), 6.67-6.69$ (d, 1H, 5'-H), 6.84-6.88 (m, 2H, 2',6'-H ), 7.327.35 (d, 2H, J = 8.01 Hz, 3,5-H ), 7.74 (s, 1H, olefin-H), 7.79-7.81 (d, 2H, J = 8.08 Hz, 2,6-H ), 9.74 (s,1H, -OH ), 12.96 (s, $1 \mathrm{H}, \mathrm{COOH})$; ESI-MS: $313.0[\mathrm{M}+\mathrm{H}]^{+}$; Anal. Calcd. for $\mathrm{C}_{18} \mathrm{H}_{16} \mathrm{O}_{5}$ : C 69.22, $\mathrm{H}$ 5.16. Found: C 69.31, H 5.23.

(Z)-3-(3,4-dihydroxyphenyl)-2-(4-methylbenzoyl)propenoic acid (3k): Yield: 35 \%; mp: 189-191 ${ }^{\circ} \mathrm{C}$ (petroleum ether-EtOAc); IR $\left(v_{\text {max., }} \mathrm{cm}^{-1}\right)$ : 3377, 1680, 1647, 1604, 1253; ${ }^{1} \mathrm{H}-\mathrm{NMR} \delta: 2.35$ (s, 3H, $\mathrm{OCH}_{3}$ ), 6.62-6.65 (d, 1H, 5'-H), 6.71 (m, 2H, 2',6'-H ), 7.29-7.33 (d, 2H, J = 8.06 Hz, 3,5-H ), 7.59 (s, 1H, olefin-H), 7.75-7.78 (d, 2H, J = 8.04 Hz, 2,6-H), 9.25 (broad s, 1H, OH), 9.52 (broad s, 1H, OH), 12.59 (broad s, $1 \mathrm{H}, \mathrm{COOH})$ ESI-MS: $298.9[\mathrm{M}+\mathrm{H}]^{+}$; Anal. Calcd. for $\mathrm{C}_{17} \mathrm{H}_{14} \mathrm{O}_{5}$ : C 68.45, H 4.73. Found: C 68.49, H 4.61.

(Z)-3-(3,4-dihydroxyphenyl)-2-(4-methoxybenzoyl)propenoic acid (3l): Yield: 13 \%; mp: 166-168 ${ }^{\circ} \mathrm{C}$ (petroleum ether-EtOAc); IR ( $\left.v_{\text {max. }}, \mathrm{cm}^{-1}\right)$ : 3414, 1686, 1640, 1597, 1261; ${ }^{1} \mathrm{H}-\mathrm{NMR} \delta$ : 3.82(s, 3H, $\mathrm{OCH}_{3}$ ), 6.63-6.66 (m,1H, 5'-H), 6.73-6.75 (m, 2H, 2',6'-H), 7.02-7.05 (d, 2H, J = $8.90 \mathrm{~Hz}, 3,5-\mathrm{H}$ ), 7.62 (s, 1H, olefin-H), 7.82-7.85 (d, 2H, J = 8.84 Hz, 2,6-H ), 9.64 (s, 1H, 4'-OH ), 9.69 (s, 1H, 3'-OH ), 12.84 (broad s, $1 \mathrm{H}, \mathrm{COOH}$ ); ESI-MS: $314.9[\mathrm{M}+\mathrm{H}]^{+}$; Anal. Calcd. for $\mathrm{C}_{17} \mathrm{H}_{14} \mathrm{O}_{6}$ : C 64.97, H 4.49. Found: C 64.83, H 4.56.

(Z)-3-(1,3-benzodioxol-5-yl)-2-(4-methoxybenzoyl)propenoic acid (3m): Yield: 39 \%; mp: 167-169 ${ }^{\circ} \mathrm{C}$ (EtOH-H $\left.{ }_{2} \mathrm{O}\right)$; IR $\left(v_{\text {max. }}, \mathrm{cm}^{-1}\right)$ : 3428, 1695, 1656, 1598, 1245; ${ }^{1} \mathrm{H}-\mathrm{NMR} \delta: 3.83$ (s, 3H, $\left.\mathrm{OCH}_{3}\right), 6.00(\mathrm{~s}$, $2 \mathrm{H}, \mathrm{OCH}_{2} \mathrm{O}$ ), 6.81-6.82 (d, $\left.1 \mathrm{H}, \mathrm{J}=1.47 \mathrm{~Hz}, 2^{\prime}-\mathrm{H}\right), 6.88-6.90$ (d, $1 \mathrm{H}, \mathrm{J}=8.10 \mathrm{~Hz}, 5^{\prime}-\mathrm{H}$ ), 6.98-7.01 
(dd, 1H, J = 8.22 Hz, J = 1.50 Hz, 6'-H ), 7.04-7.07 (d, 2H, J = 8.79 Hz, 3,5-H), 7.74 (s, 1H, olefin-H), 7.84-7.87 (d, 2H, J = 8.83 Hz, 2,6-H ), 13.01 (s, 1H, COOH); ESI-MS: 326.9 [M+H] ${ }^{+}$; Anal. Calcd. for $\mathrm{C}_{18} \mathrm{H}_{14} \mathrm{O}_{6}$ : C 66.26, H 4.32. Found: C 66.14, H 4.26.

(Z)-3-(4-chlorophenyl)-2-(4-methoxybenzoyl)propenoic acid (3n): Yield: 21 \%; mp: 167-168 ${ }^{\circ} \mathrm{C}$ $\left(\right.$ EtOH-H $\left.{ }_{2} \mathrm{O}\right)$; IR $\left(v_{\text {max. }}, \mathrm{cm}^{-1}\right)$ : 3391, 1692, 1650, 1251; ${ }^{1} \mathrm{H}-\mathrm{NMR} \delta: 3.83$ (s, 3H, $\left.\mathrm{OCH}_{3}\right), 7.03-7.06$ (d, $2 \mathrm{H}, \mathrm{J}=9.00 \mathrm{~Hz}, 2^{\prime}, 6^{\prime}-\mathrm{H}$ ), 7.39 (m, 4H, 3, 5, 3', 5'-H ), 7.82-7.86 (m, 3H, 2,6-H ), 13.29(broad s, 1H, $\mathrm{COOH}$ ); ESI-MS: $316.9[\mathrm{M}+\mathrm{H}]^{+}$; Anal. Calcd. for $\mathrm{C}_{17} \mathrm{H}_{13} \mathrm{ClO}_{4}$ : C 64.46, H 4.14. Found: C 64.57, $\mathrm{H}$ 4.04.

(Z)-3-(3-hydroxyphenyl)-2-(4-methoxybenzoyl)propenoic acid (3o): Yield: $21 \%$; mp: 108-110 ${ }^{\circ} \mathrm{C}$ (petroleum ether-EtOAc); IR ( $\left.v_{\text {max. }} \mathrm{cm}^{-1}\right)$ : 3450, 1699, 1655, 1273; ${ }^{1} \mathrm{H}-\mathrm{NMR} \delta: 3.82\left(\mathrm{~s}, 3 \mathrm{H}, \mathrm{OCH}_{3}\right)$, 6.71-6.81 (m, 3H, 2',3',6'-H), 7.02-7.05 (d, 2H, J = 8.53 Hz, 3,5-H ), 7.07-7.09 (m, 1H, 5'-H ), 7.69 (s, $1 \mathrm{H}$, olefin-H), 7.82-7.85 (d, 2H, J = $8.64 \mathrm{~Hz}, 2,6-\mathrm{H}$ ), 9.51 (broad s, 1H, 3'-OH ), 12.90 (broad s, 1H, $\mathrm{COOH}$ ); ESI-MS: $299.0[\mathrm{M}+\mathrm{H}]^{+}$; Anal. Calcd. for $\mathrm{C}_{17} \mathrm{H}_{14} \mathrm{O}_{5}$ : C 68.45, H 4.73. Found: C 68.57, $\mathrm{H}$ 4.69 .

\section{Aldose reductase inhibitory assay}

Rat lenses were homogenized at $4{ }^{\circ} \mathrm{C}$ in $135 \mathrm{mM}$ potassium phosphate buffer, $\mathrm{pH} 7.0$, containing $120 \mathrm{mM}$ lithium sulfate. The homogenate was centrifuged at 10,000 r.p.m. at $4{ }^{\circ} \mathrm{C}$ for $20 \mathrm{~min}$, and the supernatant fraction was collected and used for the enzymatic assay. The assay for in vitro ALR2 inhibitory activity of test compounds was performed in a 96-well plate. Initiation of the reaction was preceded by a $10 \mathrm{~min}$ preincubation at $37^{\circ} \mathrm{C}$ of $100 \mathrm{mM}$ potassium phosphate buffer, $\mathrm{pH} 7.0(200 \mu \mathrm{L})$, containing suitable amount of enzyme solution and test compounds. The reaction was initiated by the addition of NADPH $(0.15 \mathrm{mM})$ and $D, L$-glyceraldehyde $(5 \mathrm{mM})$, the reaction mixture was incubated at $37{ }^{\circ} \mathrm{C}$ for $20 \mathrm{~min}$, and the absorbance at $340 \mathrm{~nm}$ was recorded on a SPECTRAmax Plus 384 reader. The appropriate blanks were prepared to correct for nonspecific oxidation of NADPH and absorption of the reagents and the compounds tested. The test compounds were initially assayed for their inhibition of ALR2 at a concentration of $10 \mu \mathrm{g} / \mathrm{mL}$. If an inhibition of more than $50 \%$ was observed, the compound was classified as active. Those that exhibited more than $50 \%$ inhibition at the initial concentration were tested at eight concentrations with two replicates at each concentration to obtain their $\mathrm{IC}_{50}$ values with the Xlfit software.

\section{Computational methods}

Molecular modeling and graphics manipulations were performed using the SYBYL 6.91 software package [19] running on a Silicon Graphics Fuel workstation. The molecular model of compound 3k was constructed using SYBYL Sketch module, with the carboxylate group taken as dissociated, and then optimized by applying the Powell algorithm (Tripos force field, Gasteiger-Huckel charges). The crystal structure of the ternary complex which included cofactor NADP ${ }^{+}$and IDD594 was used for docking as a complex directly after the backbone and side chains were fixed. Finally, compound 3k was set up for docking with FlexX 1.12. 


\section{Acknowledgements}

The authors are grateful to Ms. Wen Li and Ms. Ai-Hua Song (Analytical Department of Shenyang Pharmaceutical University, Shenyang, P. R. China) for ${ }^{1} \mathrm{H}-\mathrm{NMR}$, IR and mass spectroscopy data. Our thanks also give to Dr. Jian Wang for performing molecular modeling.

\section{References}

1. Yabe-Nishimura, C. Aldose reductase in glucose toxicity: a potential target for the prevention of diabetic complications. Pharmacol. Rev. 1998, 50, 21-33.

2. Settimo, F. D.; Primofiore, G.; Motta, C. L.; Sartini, S.; Taliani, S.; Simorini, F.; Marini, A. M.; Lavecchia, A.; Novellino, E.; Boldrini, E. Naphtho[1,2-d]isothiazole acetic acid derivatives as a novel class of selective aldose reductase inhibitors. J. Med. Chem. 2005, 48, 6897-6907.

3. Van Zandt, M. C.; Jones, M. L.; Gunn, D. E.; Geraci, L. S.; Jones, J. H. Discovery of 3-[(4,5,7trifluorobenzothiazol-2-yl)methyl]indole-N-acetic acid and congeners as highly potent and selective inhibitors of aldose reductase for treatment of chronic diabetic complications. J. Med. Chem. 2005, 48, 3141-3152.

4. Stevens, J. F.; Taylor, A. V.; Nickerson, G. B.; Ivancic, M. Prenylflavonoid variation in (Humulus lupulus): distribution and taxonomic significance of xanthogalenol and 4'-O-methylxanthohumol. Phytochemistry 2000, 53, 759-775.

5. Liu, M.; Wilairat, P.; Go, M. L. Antimalarial alkoxylated and hydroxylated chalones: structureactivity relationship analysis. J. Med. Chem. 2001, 44, 4443-4452.

6. Babu, M. A.; Shakya, N.; Prathipati, P.; Kaskhedikar, S. G.; Saxena, A. K. Development of 3DQSAR models for 5-Lipoxygenase antagonists: chalcones. Bioorg. Med. Chem. 2003, 10, 40354041.

7. Kumar, S. K.; Hager, E.; Pettit, C.; Gurulingappa, H.; Davidson, N. E. Design, Synthesis, and Evaluation of Novel Boronic-Chalcone Derivatives as Antitumor Agents. J. Med. Chem. 2003, 46, 2813-2815.

8. Satyanarayana, M.; Tiwari, P.; Tripathi, B. K.; Srivastava, A. K.; Pratap, R. Synthesis and antihyperglycemic activity of chalcone based aryloxypropanolamines. Bioorg. Med. Chem. 2004, 12, 883-889.

9. Matsuda, H.; Morikawa, T.; Toguchida, I.; Yoshikawa, M. Structural requirements of flavonoids and related compounds for aldose reductase inhibitory activity. Chem. Pharm. Bull. 2002, 50, 788-795.

10. Aida, K.; Tawata, M.; Shindo, H.; Onaya, T.; Sasaki, H.; Yamaguchi, T.; Chin, M.; Mitsuhashi, H. Isoliquiritigenin: a new aldose reductase inhibitor from glycyrrhizae radix. Planta Med. 1990, 56, 254-258.

11. Severi, F.; Benvenuti, S.; Costantino, L.; Vampa, G.; Michele, M.; Antolini, L. Synthesis and activity of a new series of chalcones as aldose reductase inhibitors. Eur. J. Med. Chem. 1998, 33, 859-866. 
12. Wang, S. J.; Zhang, Z. Y.; Wu, J.; Zhou, W. F.; Cheng, M. S. Synthesis and aldose reductase inhibitory activity of $\alpha$-(phenylmethylene)- $\beta$-oxo-benzenepropanoic acid derivatives. Chin. J. Med. Chem. 2006, 16, 1-5.

13. Milcent, R.; Malanda, J. C.; Barbier, G.; Vaissermann, J. Synthesis of ethyl 2-aminodihydro-5pyrimidincarboxylate derivatives and 3,7-diethoxycarbonyl-4,6-dihydro-2,4,6,8-tetraaryl-1Hpyrimido [1,2-a]pyrimidines. J. Heterocyclic Chem. 1997, 34, 329-336.

14. Halder, A. B.; Crabbe, M. J. Bovine lens aldehyde reductase (aldose reductase). Purification, kinetics and mechanism. Biochem. J. 1984, 219, 33-39.

15. Rarey, M.; Kramer, B.; Lengauer, T.; Klebe, G. A fast flexible docking method using an incremental construction algorithm. J. Mol. Biol. 1996, 261, 470-489.

16. Chung, S.; LaMendola, J. Cloning and sequence determination of human placental aldose reductase gene. J. Biol. Chem. 1989, 264, 14775-14777.

17. Urzhumtsev, A.; Tête-Favier, F.; Mitschler, A.; Barbanton, J.; Barth, P.; Urzhumtseva, L.; Biellmann, J. F.; Podjarny, A. D.; Moras, D. A 'specificity' pocket inferred from the crystal structures of the complexes of aldose reductase with the pharmaceutically important inhibitors tolrestat and sorbinil. Structure 1997, 5, 601-612.

18. Podjarny, A.; Cachau, R. E.; Schneider, T.; Van Zandt, M.; Joachimiak, A. Subatomic and atomic crystallographic studies of aldose reductase: implications for inhibitor binding. Cell. Mol. Life Sci. 2004, 61, 763-773.

19. SYBYL Molecular Modelling System, version 6.9.1; Tripos Inc.: St. Louis, MO, 2003.

Sample Availability: Available from the authors.

(C) 2007 by MDPI (http://www.mdpi.org). Reproduction is permitted for noncommercial purposes. 